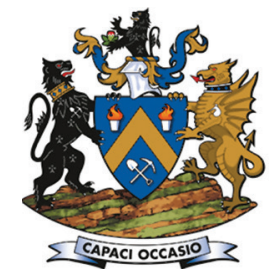

Affiliation:

1 University of Johannesburg, Doornfontein campus, Johannesburg, South Africa.

2 Mintek, Randburg, South Africa.

3 University of the Witwatersrand, Johannesburg, South Africa.

Correspondence to:

J.D. Steenkamp

Email:

JoaletS@mintek.co.za

\section{Dates:}

Received: 18 Jan. 2019

Revised: 17 Apr. 2020

Accepted: 3 May 2020

Published: November 2020

\section{How to cite:}

Thethwayo, B.M. and

Steenkamp, J.D. 2020

A review of carbon-based

refractory materials and their applications.

Journal of the Southern African Institute of Mining and Metallurgy, vol. 120 , no. 11 , pp. 641-650

\section{DOI ID:}

http://dx.doi.org/10.17159/24119717/1011/2020

ORCID

B.M. Thetwayo

https://orchid.org/0000-00019929-8828

\title{
A review of carbon-based refractory materials and their applications
}

\author{
B.M. Thethwayo ${ }^{1}$ and J.D. Steenkamp ${ }^{2,3}$
}

\section{Synopsis}

Although carbon is typically considered a reductant in pyrometallurgical smelting processes, it can also be applied as refractory material in the furnace containment system. The paper introduces researchers, new to the field, to refractory materials and the role they play in the design of the furnace containment system. It also provides an overview of carbon-containing and carbon-based refractory materials and their respective applications, including the refractory lining of the furnace containment system. The industries discussed include iron and steel making, ferro-alloys (silicomanganese), and platinum group metals.

\section{Keywords}

refractories, carbon-containing, carbon-based, graphite, carbon.

\section{Introduction}

Pyrometallurgy is the branch of science and technology concerned with the use of high temperatures to extract and purify metals (Stevenson, 2010). Smelting is the liquid-state processing applied in pyrometallurgy to extract the primary alloy from the ore, often through carbonaceous reduction processes. The vessels used are typically referred to as furnaces or smelters. Refining of the primary alloy is a further liquid-state processing step that could also occur in a ladle. Refractory materials form part of a containment system that serves to contain the high-temperature process materials, allowing the chemical reactions to occur and preserving the energy required for, or generated by, the process. Refractory materials are often referred to as the refractory lining (Steenkamp, Denton, and Hayman, 2017) and are typically supported by a steel structure. An additional function of the refractory lining is therefore to restrict the temperature of the support structure to levels that will maintain structural integrity (Schacht, 2004; Brosnan, 2004).

Although carbon is typically used as a reductant in smelting processes, it can also be applied as refractory material in the containment system. The authors both completed their PhD studies at the University of Pretoria, graduating in 2014 and 2019 respectively, focusing on various problems associated with the application of carbon as refractory material. The results of their work have been presented elsewhere (Steenkamp, 2014; Steenkamp, Pistorius, and Tangstad, 2015a, 2015b, 2015c); Thethwayo, 2019; Thethwayo and Cromarty, 2015a, 2015b; Thethwayo and Garbers-Craig, 2012, 2014). As both researchers would like to encourage further research in the field, the intention with the paper presented here is to introduce new researchers to refractory materials and the role they play in furnace design, and specifically to provide an overview of carbon-containing and carbon-based refractory materials and their applications.

\section{Background}

\section{Refractory lining design philosophies}

In the containment system, the refractory lining can serve either as a thermal insulator or as a heat conductor (Lindstad and Aursjø, 2018; Carniglia and Barna, 1992). Service is dependent on the philosophies applied to the containment system design, whether insulating or conductive, as depicted in Figure 1 (Steenkamp, Denton, and Hayman, 2017). Note that the refractory lining often consists of layers of different materials based on their thermal conductivity, gas permeability, temperatures the material can withstand, resistance to chemical wear by process material (in insulating designs), and cost. 


\section{A review of carbon-based refractory materials and their applications}

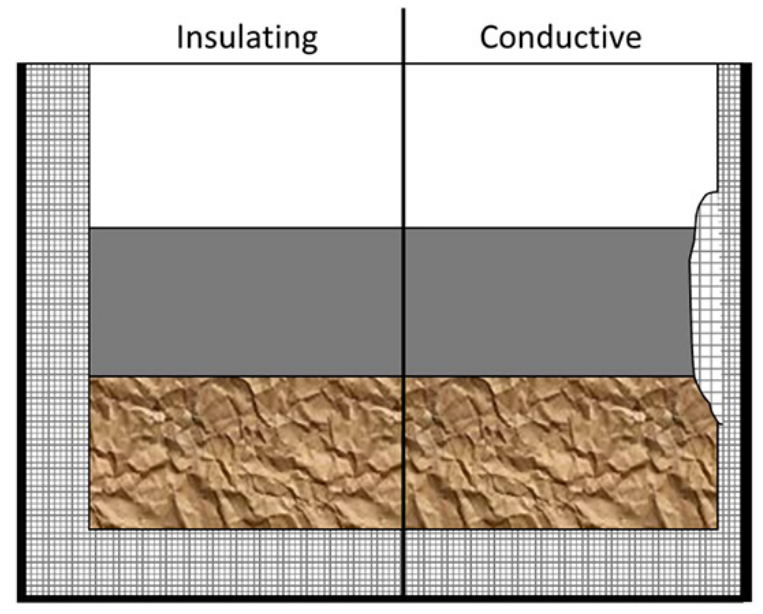

\begin{tabular}{|c|c|}
\hline & LEGEND \\
\hline & PROCESS \\
\hline & Gas or solid burden \\
\hline & Slag \\
\hline D圆 & Alloy \\
\hline & CONTAINMENT \\
\hline & Steel shell \\
\hline & Refractory material \\
\hline 目曲 & $\begin{array}{l}\text { Frozen layer of } \\
\text { process material }\end{array}$ \\
\hline
\end{tabular}

Figure 1-Conceptual layout of the furnace containment system for an insulating refractory lining design (left) and a conductive lining design (right) (Steenkamp, Denton, and Hayman, 2017)

In an insulating lining design, the refractory material serves as a thermal insulator with its low thermal conductivity (often obtained by using materials with a low specific thermal conductivity and a thicker lining), resulting in minimal heat transfer to the surroundings. This results in the furnace shell being protected, the heat being retained within the vessel as heat losses to the environment are minimal, and the process temperature being maintained (Lindstad and Aursjø, 2018; Duncanson and Toth, 2004; Steenkamp, Denton, and Hayman, 2017). The refractory materials are typically in contact with the liquid process materials, which can potentially be very corrosive towards the refractory. It is therefore essential to select refractory materials that are compatible with the process materials at the operating conditions, these refractory material properties (chemistry, phase chemistry, and porosity) all playing a role in the selection process (Lindstad and Aursjø, 2018; Steenkamp, Denton, and Hayman, 2017).

For an insulating lining, the inner lining (hot face) consists of oxide refractories while the cold face is typically a steel shell. The insulating material protects the steel shell against high operating temperatures. Temperatures are high through the insulating lining since there is no deep cooling on the cold face, and the temperature gradient from the hot face to the cold face is minimal (Lindstad and Aursjø, 2018).

A freeze lining, or conductive lining, design philosophy comprises a refractory material with high thermal conductivity (and often with a thinner wall or bottom) in conjunction with a robust cooling system to extract the heat away from the refractory material (Lindstad and Aursjø, 2018; Duncanson and Toth, 2004). The material in the hot face (inner lining) has to have a high thermal conductivity in order to conduct the heat away from the hot face. The cold face or outer surface of the lining typically has a steel shell with closed water channels or water sprays; copper coolers are also used for cooling in the conductive lining design (Lindstad and Aursjø, 2018; Thethwayo, 2019). For a conductive lining, the hot face of the lining is kept at a temperature lower than the melting temperature of the melt. This is achieved through the effective extraction of heat through a conductive lining and deep cooling from the cold face.

Owing to the low temperature at the inner surface (hot face), the melt (process materials) freezes on the inner surface of the lining forming a solid, frozen protective layer (as shown in Figure 1). This solid layer prevents the liquid process material from corroding the refractory material. In a conductive lining design, it is the physical properties of the refractory material that are of importance, more specifically its thermal conductivity (Duncanson and Toth, 2004).

Carbon, with its high thermal conductivity, high mechanical strength, and ability to withstand temperatures above $3000^{\circ} \mathrm{C}$ is a typical refractory material used at the hot face in conductive lining designs (Lindstad and Aursjø, 2018).

The drawbacks with using carbon against a hot melt are as follows.

- Carbon is a reductant in most processes, therefore the refractory can be consumed as a reductant

- Molten metals can dissolve substantial amounts of carbon

> Carbon is susceptible to oxidation (Lindstad and Aursjø, 2018).

\section{Classification of refractory materials}

Typically, refractory materials are based on one or more of six high melting-point, crystalline oxides $\left(\mathrm{Al}_{2} \mathrm{O}_{3}, \mathrm{CaO}, \mathrm{Cr}_{2} \mathrm{O}_{3}, \mathrm{MgO}\right.$, $\mathrm{SiO}_{2}, \mathrm{ZrO}_{2}$ ), as well as carbon, or a combination of these (Ewais, 2004; Carniglia and Barna, 1992; Routschka and Barthel, 2008).

Refractory materials can be classified according to their chemical composition as follows (Banerjee, 2004; Amavis, 1990; Carniglia and Barna, 1992):

- Basic: Calcia (CaO), magnesia ( $\mathrm{MgO})$, doloma (CaO$\mathrm{MgO})$, magnesia-chromite $\left(\mathrm{MgO} \mathrm{Cr}_{2} \mathrm{O}_{3}\right)$, chromite $\left(\mathrm{Cr}_{2} \mathrm{O}_{3}\right)$, and spinels (typically $\mathrm{MgO}-\mathrm{Al}_{2} \mathrm{O}_{3}$ )

- Non-basic (acidic): Alumina-silica based materials such as alumina $\left(\mathrm{Al}_{2} \mathrm{O}_{3}\right)$, fireclays $\left(\mathrm{Al}_{2} \mathrm{O}_{3}-\mathrm{SiO}_{2}\right)$, silica $\left(\mathrm{SiO}_{2}\right)$, and calcium aluminate $\left(\mathrm{CaO}-\mathrm{Al}_{2} \mathrm{O}_{3}\right)$

- Oxide-carbon: Magnesia-carbon (MgO-C), calciamagnesia-carbon ( $\mathrm{CaO}-\mathrm{MgO}-\mathrm{C}$ ), alumina-carbon $\left(\mathrm{Al}_{2} \mathrm{O}_{3}-\mathrm{C}\right)$, alumina silicon carbide-carbon $\left(\mathrm{Al}_{2} \mathrm{O}_{3}-\mathrm{SiC}-\mathrm{C}\right)$, and fireclay silicon carbide-carbon $\left(\mathrm{Al}_{2} \mathrm{O}_{3}-\mathrm{SiO}_{2}-\mathrm{SiC}-\mathrm{C}\right)$

- Specialized: Carbon (C), graphite (C), zirconia $\left(\mathrm{ZrO}_{2}\right)$, carbides (SiC, TiC), nitrides (BN, AlN, SiN), and borides $\left(\mathrm{TiB}_{2}\right)$.

The carbon-containing or carbon-based refractory materials of interest to the discussion presented here are oxide-carbon 


\section{A review of carbon-based refractory materials and their applications}

\begin{tabular}{|c|c|}
\hline Formula & Application \\
\hline $3 \mathrm{Al}_{2} \mathrm{O}_{3}-2 \mathrm{SiO}_{2}$ & Steelmaking \\
\hline $\mathrm{Al}_{2} \mathrm{O}_{3}$ & Ducting, laboratory ware, laboratory tube furnaces \\
\hline $\mathrm{Al}_{2} \mathrm{O}_{3}-\mathrm{C}$ & Submerged entry pour tubes, nozzles and shrouds, continuous steel casting, monoblock stoppers and sliding gate valves (Chen et al., 2018; Wang et al., 2018) \\
\hline $\mathrm{Al}_{2} \mathrm{O}_{3} \mathrm{SiC}-\mathrm{C}$ & Iron and steel making (hot metal pre treatment vessels, blast furnace tap-holes, troughs, and torpedo ladles), heat exchangers \\
\hline $\mathrm{Al}_{2} \mathrm{O}_{3}-\mathrm{SiO}_{2}$ & Blast furnaces, aluminium smelters \\
\hline $\mathrm{Al}_{2} \mathrm{O}_{3}-\mathrm{SiO}_{2} \mathrm{SiC}-\mathrm{C}$ & Iron and steel making (blast furnace tap-holes, troughs and torpedo ladles) \\
\hline C & $\begin{array}{l}\text { Alumina smelters, steelmaking, ferroalloy production, and PGM smelters (Steenkamp, Pistorius, and Tangstad, 2015a; Thethwayo, 2019; Thethwayo and } \\
\text { Cromarty, 2015a, 2015b; Thethwayo and Garbers-Craig, 2012, 2014) }\end{array}$ \\
\hline $\mathrm{CaMg}\left(\mathrm{CO}_{3}\right)_{2}$ & Blast furnaces \\
\hline $\mathrm{CaO}$ & Heat exchangers \\
\hline $\mathrm{CaO}-\mathrm{MgO}$ & Glass furnaces \\
\hline $\mathrm{Cr}_{2} \mathrm{O}_{3}$ & Glass furnaces \\
\hline $\mathrm{Cr}_{2} \mathrm{O}_{3}-\mathrm{Al}_{2} \mathrm{O}_{3}$ & Fibreglass and insulation wool production \\
\hline $\mathrm{Cr}_{2} \mathrm{O}_{3}-\mathrm{FeO}$ & Glass furnaces \\
\hline $\mathrm{Cr}_{2} \mathrm{O}_{3}-\mathrm{MgO}$ & Cement kilns \\
\hline $\mathrm{MgO}$ & Glass furnaces, kilns \\
\hline $\mathrm{MgO}-\mathrm{Al}_{2} \mathrm{O}_{3}$ & Glass furnaces, kilns \\
\hline $\mathrm{MgO}-\mathrm{C}$ & Basic oxygen furnaces, electric arc furnaces, and steel reining ladles utilized in steel making \\
\hline $\mathrm{MgO}-\mathrm{CaO}$ & Rotary kilns, glass furnaces \\
\hline $\mathrm{MgO}-\mathrm{CaO}-\mathrm{C}$ & Steel refining ladles, basic oxygen furnace (not on slag line) \\
\hline $\mathrm{MgO}-\mathrm{Cr}_{2} \mathrm{O}_{3}$ & Cement kilns, glass furnace, nonferrous metal production \\
\hline $\mathrm{MgO}-\mathrm{nAl}_{2} \mathrm{O}_{3}$ & Steel making and cement kilns \\
\hline${\mathrm{MgO}-\mathrm{ZrO}_{2}}$ & Cement kilns \\
\hline $\mathrm{SiC}$ & Blast furnaces, zinc production, kilns \\
\hline $\mathrm{SiO}_{2}$ & Laboratory ware, nozzles, troughs for Al and Cu production \\
\hline $\mathrm{ZrO}_{2}$ & Induction furnaces (steel making) \\
\hline $\mathrm{ZrO}_{2}-\mathrm{C}$ & Continuous casting hollow ware \\
\hline $\mathrm{ZrO}_{2}-\mathrm{SiO}_{2}$ & Blast furnaces \\
\hline $\mathrm{ZrO}_{2}-\mathrm{SiO}_{2}-\mathrm{Al}_{2} \mathrm{O}_{3}$ & Glass furnaces \\
\hline
\end{tabular}

or specialized refractory materials. A summary of the common refractory materials and their applications is presented in Table I, with the materials of interest highlighted.

Refractory materials can also be classified according to their form: they are either pre-shaped or unshaped (monolithic) products. Pre-shaped refractory materials can be either fired or unfired. Fired refractory products are pre-treated at elevated temperatures to remove moisture, volatiles, and bonded water. Firing also densifies the refractory. Unshaped (monolithic) refractory materials include plastic mixes, castables, rammables, vibrateables, gunning, fettling, coating, and mortars (Banerjee, 2004).

\section{Components of refractory material}

The major components of a refractory material are the aggregate, matrix, and pores (Landy, 2004).

\section{Aggregates}

Aggregates are the primary building blocks of the refractory material and comprise particles exceeding $200 \mu \mathrm{m}$ in size. They form the bulk of the refractory material and accounts for up to $70 \%$ of its weight by mass (Landy, 2004).

\section{Matrix}

A matrix is sintered fine materials which hold together the larger and smaller aggregate particles, either in bonded bricks or in monolithic refractory materials (Brosnan, 2004; Lee and Zhang, 1999; Barthel, 2008). It typically consists of a binder phase as well as fillers added to improve the properties of the refractory material (Pierson, 1993; Landy, 2004).

Binders can be inorganic or organic. Inorganic binders include various clay materials, soluble sulphates, phosphoric acid, boric acid, and some phosphates, among others (Landy, 2004). Organic binders are pitches and resins. Pitch bonds graphitize at higher temperatures and give better oxidation resistance than resin (Richmond, 2004). Pitches originate from coal and petroleum, they contain dangerous carcinogenic hydrocarbons, and therefore are applied less. Resins applied in refractory materials typically also originate from coal and petroleum, but they are environmentally friendlier than the pitches. Resins also require less energy to produce than pitches require (Landy, 2004). Resin bonds typically have higher strength and emit less fumes (Richmond, 2004).

Fillers are used to pack the spaces between the aggregate material. Their particle size is typically $<1 \mu \mathrm{m}$ (Landy, 2004). Additives are fillers used to enhance the wear resistance of the brick (Nitta, Nakamura, and Ishii, 2008), and are discussed further in the subsequent section in the context of carbon as refractory material. 


\section{A review of carbon-based refractory materials and their applications}

\section{Pores}

Pores are unfilled or void spaces in the refractory structure (Landy, 2004). Pores can be present both in the aggregate and in the binder phase; usually the matrix has more pores and impurities than the aggregate particles. In refractory materials, pores are classified as apparent porosity (open pores) and closed porosity. Open pores can be penetrated by liquids (alloys, mattes, or slags), whereas closed pores are not easily penetrated (Brosnan, 2004). The porosity of a refractory is expressed as the average percentage of pore volume in the total refractory volume (Carniglia and Barna, 1992).

\section{Refractory wear mechanisms}

In order to understand the role carbon plays in improving the properties of refractory materials in specific applications, it is important to identify the refractory wear mechanisms applicable. Wear of a refractory material by a liquid melt can proceed through corrosion or mechanical (physical) wear. Although contact between the liquid melt and refractory material would be of major concern when an insulating design philosophy is applied, it is also relevant to a conductive design when cooling of the refractory is insufficient to form a freeze lining at the interface between the refractory and liquid process material.

Corrosion was mentioned when the two refractory lining design philosophies were introduced. In the context of refractory materials, corrosion can be defined as any type of interaction between a solid and a fluid phase that results in damage to either of the phases (Jansson, Brabie, and Bohlin, 2004). Corrosion of a refractory material is characterized by loss of thickness and mass (Brosnan, 2004).

The first stage of corrosion involves penetration of the liquid melt into the immediate hot face of the refractory material. If the temperature of the refractory drops below the solidus temperature of the liquid melt, the melt freezes and penetration ceases (Brosnan, 2004). If the melt does not freeze, it infiltrates into the capillaries of the refractory material; this is the second stage of corrosion. The liquid melt penetrates the refractory material through capillary suction, which affects the matrix of the refractory (Brosnan, 2004). Infiltration typically occurs where there are large temperature gradients from the hot face to the cold face of the refractory material. The third stage of corrosion is when the refractory material is infiltrated by the liquid melt to such an extent that the aggregate is held together by the melt as the matrix has been corroded (Brosnan, 2004).

Penetration and infiltration of the refractory material by the liquid melt is typically affected by the porosity and wettability of the refractory, viscosity and surface tension of the melt, contact time, and temperature (Lee and Zhang, 1999; Jansson, Brabie, and Bohlin, 2004; Silva et al., 2005; Carniglia and Barna, 1992).

Open porosity is a measure of the effective pore volume in the refractory into which the liquid can penetrate. The porosity of a refractory is expressed as the average percentage of pore volume in the total refractory volume. The resistance of a refractory to penetration by liquids is improved by reducing the open porosity. If the microstructure of the refractory has open joints, cracks, or gaps, the liquid invasion can be very rapid and proceed through the full extent of the refractory wall. If the refractory has connected pores the liquid invasion can be rapid but it occurs progressively. If the refractory is chemically bonded or has a matrix, the liquid invasion is moderate and progressive (Carniglia and Barna, 1992).
Wetting is characterized by a contact angle between a solid refractory and a liquid. A contact angle of $<90^{\circ}$ is regarded as wetting and a contact angle $>90^{\circ}$ is non wetting. In general, an increase in temperature will increase wettability (Bhoi, Ray, and Sahajwalla, 2008). An increase in temperature also enhances reactions and decreases surface tension of the liquid (Bhoi, Ray, and Sahajwalla, 2008). A wetting angle less than $90^{\circ}$ enhances the penetration depth of liquid through a refractory (Lee and Zhang, 2004; Jansson, Brabie, and Bohlin, 2004).

The viscosity of the melt affects the penetration and dissolution of the refractory. A slag with low viscosity will be more likely to penetrate and dissolve the refractory (Lee and Zhang, 1999).

Resistance to corrosion or compatibility of a refractory material with a liquid melt is defined as the ability of the refractory to resist penetration of, or chemical reaction with, or dissolution into, a liquid melt (Lee and Zhang, 2004). The best refractory material should therefore have a low solubility in the liquid melt (Lee and Zhang, 2004), a high resistance to chemical reaction with the liquid melt (Rigaud, 2011), and a high resistance to penetration by the liquid melt it is exposed to.

Mechanical or physical wear involves erosion (Lee and Zhang, 2004). Erosion is abrasion of a refractory material and occurs mainly when the material exposed to gas and slag movement (Jansson, Brabie, and Bohlin, 2004).

\section{Carbon in refractory materials}

Carbon is an element that can occur in nature in three forms: diamond, graphite, and coal (Ewais, 2004). Carbon has excellent refractory properties such as non-wettability by slag and high thermal conductivity (Lee and Zhang, 1999; Barthel, 2008). It can be used as a refractory in two forms: as an additive or a binder (coal tar, petroleum pitch, or resin) in carbon-containing refractory materials, and also as aggregate in carbon-based refractory materials (Lee and Zhang, 2004; Barthel, 2008).

In the remainder of the paper, carbon-based and carboncontaining refractory materials are discussed in more detail. As an introduction, the common additives used in carbon-based refractory materials are listed and discussed:

Antioxidants: Antioxidants reduce carbon oxidation by undergoing preferential oxidation, which decreases the oxygen partial pressure inside the refractories. The oxide compounds that are formed block pores to limit liquid penetration and prevent the exchange of atmosphere, essentially protecting the carbon from oxidation (Yao et al., 2017). Antioxidants or oxygen inhibitors delay carbon debonding and graphite oxidation (Rigaud, 2011). Typical antioxidants used in MgO-C brick are Al, Si, AlSi, AlCaSi, AlCr, $\mathrm{Mg}$, AlMg, $\mathrm{Al}-\mathrm{B}_{4} \mathrm{C}, \mathrm{B}_{4} \mathrm{C}$, and $\mathrm{ZrB}_{2}$, among others (Ewais, 2004; Yao et al., 2018; Liao et al. 2018). Al is the most common antioxidant; it can react with carbon to form $\mathrm{Al}_{4} \mathrm{C}_{3}$, which causes a substantial volume effect. The drawback with $\mathrm{Al}_{4} \mathrm{C}_{3}$ is that it undergoes hydration to $\mathrm{Al}(\mathrm{OH})_{3}$, which leads to a large volume expansion (Yao et al., 2017). $\mathrm{B}_{4} \mathrm{C}$ promotes the crystallization and graphitization of the resin carbon and thus improves its resistance to oxidation (Liao et al., 2018).

$\mathrm{Al}_{2} \mathrm{O}_{3}$ : Addition of alumina improves the resistance to erosion (mechanical wear), alkali attack, and dissolution by the liquid metal (Tomala and Basista, 2007).

Boron-based additives: Boron compounds block open pores and reduce oxidation by formation of liquid phases (Lee and Zhang, 1999). Borides are seldom used because of their high cost (Yao et al., 2017). 


\section{A review of carbon-based refractory materials and their applications}

$\mathrm{CaO}, \mathrm{CaO} \mathrm{MgO}$, and $\mathrm{CaMg}\left(\mathrm{CO}_{3}\right)_{2}$ are common basic slag additives which are added to refractory materials used in primary steelmaking as they retard the dissolution of refractory materials (Lee and Zhang, 1999).

Carbon: Carbon as an additive gives the refractory material specific properties. Graphite additions to oxide refractories effectively increase the refractory's thermal conductivity and also improve its thermal shock resistance. As carbon is non-wetted by slag, its presence in the refractory limits slag penetration (Lee and Zhang, 1999; Barthel, 2008; Shen, Fujii, and Nogi, 2009).

$\mathrm{MgO}$ increases the resistance to attack by molten iron (Chen et al., 2010). Addition of spinel $\left(\mathrm{Al}_{2} \mathrm{O}_{3} \mathrm{MgO}\right)$ to carbon-based refractories improves corrosion resistance to slag (Zhang and Lee, 2004).

$\mathrm{Si}$ : When $\mathrm{Si}$ is added to a carbon refractory it forms $\mathrm{SiC}$ whiskers, which reduce pore size, improve permeability, and improve abrasion resistance. $\mathrm{SiC}$ also improves the microporous structure of the material (Dzermejko, 2004). Si improves the resistance of the refractory to alkali attack by preventing the infiltration of the alkalis to the brick (Nitta, Nakamura, and Ishii, 2008). Alkalis (potassium and sodium) react with carbon to form lamellae compounds that swell, causing volume expansion and spalling of carbon. Alkalis react with the $\mathrm{SiO}_{2}$ and form compounds that do not swell, which avoids volume expansion and spalling of the refractory (Dzermejko, 2004; Tomala and Basista, 2007; Nitta, Nakamura, and Ishii, 2008).

$\mathrm{SiC}$, and $\mathrm{Si}_{3} \mathrm{~N}_{4}$ improve the corrosion resistance, and $\mathrm{SiC}$ inhibits carbon oxidation by the formation of a thin and stable layer of $\mathrm{SiO}_{2}$ at the surface of $\mathrm{SiC}$, preventing further oxidation of carbon. Addition of $\mathrm{SiC}$ to $\mathrm{ZrO}_{2}-\mathrm{C}$ enhances thermal conductivity, decreases thermal expansion, and prevents disintegration of the matrix (Ewais, 2004).

$\mathrm{TiO}_{2}$ : In blast furnace applications $\mathrm{TiO}_{2}$ is reduced to TiN, which forms a protective layer and/or reduces the flow rate of liquid iron near the surface of the refractory. $\mathrm{TiO}_{2}$ reduces slag wettability and increases slag viscosity, thus reducing slag penetration. When $\mathrm{MgO}^{-\mathrm{TiO}_{2}}$ is added to the refractory, it forms high-melting phases when it reacts with the slag (Zhang and Lee, 2004).

Metallic additives such as $\mathrm{Fe}, \mathrm{Ni}$, or Co promote the crystallization and graphitization of the resin carbon and thus improve its oxidation resistance (Liao et al., 2018).

\section{Carbon-containing refractory materials}

Carbon-containing refractories are manufactured by incorporating graphite or carbon into the oxide refractories (Chen et al., 2018). In carbon-containing refractory materials, the aggregate consists mainly of one or more of the six high melting-point oxides or their associated mineral phases. (Lee and Zhang, 1999). Carbon is typically present in the matrix either as the binder phase or as the additive, or both (Lee and Zhang, 2004). The microstructure of a typical carbon-containing refractory material is shown in Figure 2. This refractory has large grains of $\mathrm{SiO}_{2}$ as aggregate, with a carbon binder, and $\mathrm{Al}-\mathrm{Si}-\mathrm{O}_{x}$ and metallic additives forming the matrix. The metallic additives serve as antioxidants.

Carbon-containing refractory materials can further be differentiated as basic or non-basic materials.

\section{Basic carbon-containing refractory material}

Carbon-containing calcia, magnesia, and doloma (sintered dolomite) are considered as basic oxide refractory materials, with magnesia being the most commonly used (Habashi, 2002;
Lee and Zhang, 2004; Rigaud, 2011). In the 1950s and 1960s, pitch-bonded doloma, doloma magnesia, magnesia-doloma, and magnesia bricks were used in basic oxygen steelmaking furnaces. In 1970s resin-bonded magnesia-carbon refractory was introduced for electric arc furnace applications. Graphite became the principal carbon constituent in the magnesia-carbon refractory brick, where up to $35 \%$ C was added. In the 1980 s the magnesia-carbon refractory brick was introduced in basic oxygen furnaces (Landy, 2004). Today, magnesia-carbon refractory bricks are typically applied in steelmaking basic oxygen furnaces and electric arc furnaces (Lee and Zhang, 1999).

The aggregate of the magnesia-carbon refractory brick is magnesia. Magnesia-carbon refractory brick can either be pitch bonded, pitch impregnated, or synthetic resin bonded. The properties of the magnesia-carbon refractory brick vary, based on the type of bonding and the manufacturing process (Ewais, 2004). A pitch-bonded magnesia-carbon refractory brick is manufactured by hot pressing and tempering at $250-350^{\circ} \mathrm{C}$. After tempering, pitches are added under vacuum. This step produces a pitch-impregnated brick. Resin-bonded brick is manufactured cold or at temperatures less than $100^{\circ} \mathrm{C}$. Liquid phenolic resin and a hardener are used as binders. The binders are hardened at $120^{\circ} \mathrm{C}$ to $200^{\circ} \mathrm{C}$ (Ewais, 2004). The addition of carbon to magnesia bricks started in the 1980 s, with the manufacturing of resin-bonded magnesia-graphite bricks. The carbon content of the magnesia-carbon refractory brick typically ranges from $<2 \%$ to 25\% (Ewais, 2004; Lee and Zhang, 1999). The type of carbon used has an effect on the quality of the brick. Replacing carbon with graphite improves the service life of the brick, whereas adding more carbon than graphite increases the porosity. With increasing graphite, the thermal expansion of the brick is decreased, the thermal shock resistance is increased, and the resistance to thermal spalling is increased. Carbon increases the wetting angle of the brick, thereby reducing wettability and potentially increasing resistance to corrosion (Carniglia and Barna, 1992).

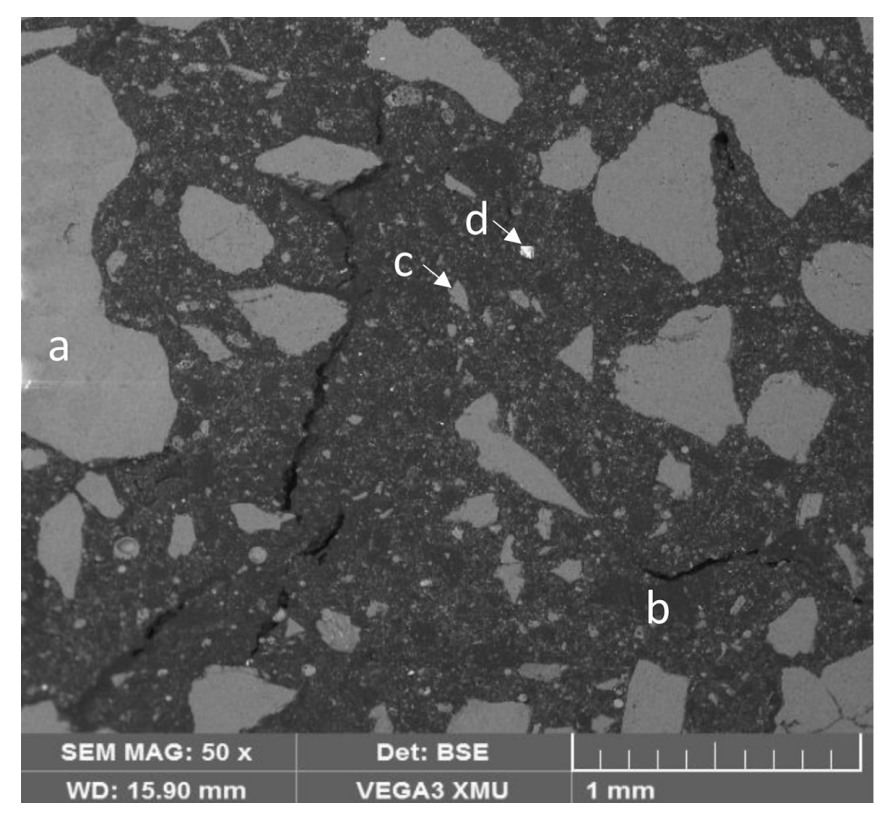

Figure 2-Backscattered electron micrograph of a carbon-containing refractory consisting of (a) aggregate- $\mathrm{SiO}_{2}$, and the matrix material consisting of (b) carbon, (c) (Al, Ca) ${ }_{2} \mathrm{SiO}_{5}$, and (d) metallics (Fe-Si, $\mathrm{Fe}$, and Ti) 


\section{A review of carbon-based refractory materials and their applications}

Carbon increases the resistance of an $\mathrm{MgO}-\mathrm{C}$ brick to penetration through the reduction of magnesia by carbon, forming gaseous $\mathrm{Mg}$ and $\mathrm{CO}$. Gaseous $\mathrm{Mg}$ can be re-oxidized to form a dense deposit of secondary $\mathrm{MgO}$ at the slag-refractory interface. In this way, secondary $\mathrm{MgO}$ prevents penetration by the melt. Gaseous $\mathrm{CO}$ and $\mathrm{Mg}$ provide internal pressure which also resists the ingress of melt (Lee and Zhang, 1999). These mechanisms further enhance the resistance of the refractory material to corrosion.

Additives preserve the carbon content of the magnesiacarbon refractory brick as they increase resistance to oxidation and corrosion. Typical additives are Al, Si, AlSi, AlCaSi, AlCr, $\mathrm{Mg}, \mathrm{AlMg}, \mathrm{Al}-\mathrm{B}_{4} \mathrm{C}$, and $\mathrm{B}_{4} \mathrm{C}$, among others (Ewais, 2004). Antioxidants protect the refractory material by forming $\mathrm{CO}$ and $\mathrm{Mg}$ gas, which act as a buffer to $\mathrm{O}_{2}$, inhibiting carbon oxidation by reducing $\mathrm{CO}$ to $\mathrm{C}$, and forming a protective oxide layer and decreasing porosity (Ewais, 2004). As an example, in the case of $\mathrm{Al}$ a dense $\mathrm{MgAl}_{2} \mathrm{O}_{4}$ spinel phase forms, which stops slag penetration and prevents corrosion.

Doloma is a $\mathrm{CaO}-\mathrm{MgO}$ refractory produced from dolomite $\left(\mathrm{CaMg}\left(\mathrm{CO}_{3}\right)_{2}\right)$ by sintering and/or fusing. Doloma refractory materials are typically used in the steel industry as linings for basic oxygen furnace converters, ladle furnaces, and electric arc furnaces (Ewais, 2004; Lee and Zhang, 1999).

One of the disadvantages of a doloma refractory material is its susceptibility to hydration. The free lime $(\mathrm{CaO})$ in the refractory brick reacts easily with water vapour or moisture (Richmond, 2004). Hydration leads to the formation of a hydroxide $\left(\mathrm{Ca}(\mathrm{OH})_{2}\right)$ and the breaking apart of grains into smaller particles (Richmond, 2004), resulting in the material being pulverized and the particles cracking (Ghasemi-Kahrizsangi et al., 2017). Magnesia refractory material is also susceptible to hydration, with similar consequences (Steenkamp et al., 2011).

Doloma-carbon refractory bricks are made by adding pitch, tar, or flake or vein graphite to the dolomite mix. Carbon addition enhances the brick's resistance to thermal shock, lowers the porosity, increases the wetting angle, and improves the hydration resistance (Ewais, 2004; Lee and Zhang, 1999). Sintered dolomite grains are typically bonded with resin or tar. The mixture is subsequently pyrolized at $200-400^{\circ} \mathrm{C}$. Organic binder can be used for high-fired brick, which is fired at high temperature and impregnated with tar (Lee and Zhang, 1999).

The corrosion resistance of doloma-carbon refractory bricks depends on the basicity of the slag that they are in contact with. For a slag with low basicity and low Fe content, the corrosion resistance of doloma carbon refractory brick is better than that of magnesia-carbon bricks. This is due to the fact that $\mathrm{CaO}$ reacts with $\mathrm{SiO}_{2}$ to form high-melting phases. For a slag with high basicity and high $\mathrm{Fe}$ content, the corrosion resistance of the magnesia-carbon refractory brick is better than that of the doloma-carbon refractory (Lee and Zhang, 1999).

\section{Non-basic carbon-containing refractory materials}

Carbon-containing alumina, alumina-silicon carbide, fireclaysilicon carbide, and zirconia are the common non-basic, oxidecarbon refractory materials applied in iron and steel making.

Alumina-carbon refractory material is typically used in iron and steel making, as well as in continuous casting submergedentry nozzles (Wang et al., 2018). Wear by oxidation of the carbon is common in this brick. Metal additives ( $\mathrm{Al}$ and $\mathrm{Si}$ ) retard carbon oxidation by preferentially reacting with oxygen.
$\mathrm{ZrO}_{2}$ grains could also be added to minimize the erosion of the refractory at the high wear zones in continuous casting. Alumina build-up, mainly from the steel being cast but also as an oxidation product when the additive reacts with oxygen, causes clogging of the submerged-entry nozzles. Formation of alumina is minimized by adding $\mathrm{CaZrO}_{3}$ (Lee and Zhang, 1999).

Alumina-silicon carbide-carbon refractory material is mostly utilized in torpedos used to transfer liquid iron and in steel ladles. To improve the resistance to slag attack, SiC is added to aluminacarbon refractories. Oxidation of $\mathrm{SiC}$ and $\mathrm{C}$ is the most prominent wear mechanism, and is minimized through the addition of suitable metallic and ceramic additives. Additives also increase the hot strength of the $\mathrm{Al}_{2} \mathrm{O}_{3}$-SiC-C refractory (Lee and Zhang, 1999).

Fireclay-silicon carbide-carbon refractory materials are used in metal pre-treatment vessels. The main wear mechanism is the oxidation of carbon, which is inhibited through the addition of $\mathrm{SiC}, \mathrm{Si}$, and $\mathrm{Si}_{3} \mathrm{~N}_{4}$. These additives also reduce slag penetration (Lee and Zhang, 1999).

Zirconia-carbon refractory materials can be used in hollow ware, i.e. continuous casting submerged entry nozzles, as they are more resistant to abrasion and erosion. The gases diffuse through the $\mathrm{ZrO}_{2}$ grain boundaries and weaken the brick such that the grains can be washed off by the slag. Graphite improves the corrosion resistance of $\mathrm{ZrO}_{2}$ by reacting with the oxide in slag and the impurities in the brick to form gaseous products. The gaseous products decrease the corrosion resistance of the zirconia-carbon refractory material. $\mathrm{Y}_{2} \mathrm{O}_{3}$ is added to increase the resistance to slag attack (Lee and Zhang, 1999).

Carbon-oxide composites are a further development in stainless steel making and have and have contributed significantly towards a dramatic reduction in refractory consumption. However, carbon-oxide refractories suffer two main drawbacks (Chen et al., 2018; Liao et al., 2018; Xiao et al., 2019):

- Molten metal like steel can pick up carbon from carboncontaining refractories. This increases the carbon content in the metal, which is not desirable for high-quality steel.

- A high graphite content accompanied with high thermal conductivity decreases the temperature of the molten metal. This can adversely affect operations like tapping (Chen $e t$ al., 2018).

Lowering the carbon content in the oxide-carbon refractories is necessary to reduce the effect of high carbon content in highquality steel production. However, this has detrimental effects on the properties of the oxide-carbon refractories. Carbon contents less than $5 \%$ by weight lead to decreased thermal diffusivity and an increased thermal expansion coefficient; subsequently, these affect the thermal shock resistance and corrosion resistance of the refractory (Chen et al., 2018; Yao et al., 2017; Wang et al., 2018).

Additives and alternative carbon sources are being investigated to attain the same refractoriness in the oxide-carbon materials with a reduced carbon content. The following additives are potential sources of carbon: $\mathrm{Ti}_{3} \mathrm{AlC}_{2}$ (Chen et al., 2018), $\mathrm{Al}_{4} \mathrm{SiC}_{4}$ (Yao et al., 2017), expanded graphite/SiC or $\mathrm{SiO}_{x}$ hybrids, activated carbon, carbon black, carbon fibres, nanocarbon, graphene, graphene oxide nanosheets, and expanded graphite (Wang et al., 2018; Xiao et al., 2019).

$\mathrm{Ti}_{3} \mathrm{AlC}_{2}$ added to an $\mathrm{Al}_{2} \mathrm{O}_{3}-\mathrm{C}$ refractory to replace carbon improves the resistance to corrosion by molten steel and slag. $\mathrm{Ti}_{3} \mathrm{AlC}_{2}$ blocks the penetration pathway of the molten steel due 


\section{A review of carbon-based refractory materials and their applications}

to the volume expansion associated with the oxidation of $\mathrm{Ti}_{3} \mathrm{AlC}_{2}$ and a refined structure. Oxidation of $\mathrm{Ti}_{3} \mathrm{AlC}_{2}$ also decreases the dissolved oxygen in the infiltrated molten steel and increases the viscosity of the infiltrate. In contact with the slag, $\mathrm{Ti}_{3} \mathrm{AlC}_{2}$ gradually decomposes and dissolves in the slag (Chen et al., 2018).

$\mathrm{Al}_{4} \mathrm{SiC}_{4}$ has a a high melting point $\left(2080^{\circ} \mathrm{C}\right)$, great hydration resistance, and it easily oxidizes at high temperatures and forms a protective layer which prevents subsequent reactions (Yao et al., 2017). When added to $\mathrm{MgO}-\mathrm{C}$ brick, $\mathrm{Al}_{4} \mathrm{SiC}_{4}$ can be oxidized to form $\mathrm{Al}_{2} \mathrm{O}_{3}-\mathrm{SiO}_{2}$ and $\mathrm{SiC}$, which can serve as a protective layer. The oxidation product $\mathrm{Al}_{2} \mathrm{O}_{3}$ can react with $\mathrm{MgO}$ to form $\mathrm{MgAl}_{2} \mathrm{O}_{4}$, which leads to volume expansion, thus reducing the porosity, $\mathrm{MgAl}_{2} \mathrm{O}_{4}$ also serves as a protective layer. $\mathrm{MgAl}_{2} \mathrm{O}_{4}$ increases the density of the refractory by filling the pores, which improves resistance to slag corrosion and permeation. Addition of $\mathrm{Al}_{4} \mathrm{SiC}_{4}$ improves the properties of the matrix in the $\mathrm{MgO}-\mathrm{C}$ refractory (Yao et al., 2017).

Carbon black can improve the thermal shock resistance when replacing graphite in the $\mathrm{Al}_{2} \mathrm{O}_{3}-\mathrm{C}$ and $\mathrm{MgO}-\mathrm{C}$ refractories. Carbon nanotubes and fibres enhance the strength and toughness of the oxide-C refractory. Addition of graphene and graphene oxide nanosheets enhances the mechanical properties. Carbon nanotubes, graphene, and graphene oxides are expensive and therefore not economical to use. The addition of expanded graphite with $\mathrm{SiC}$ or $\mathrm{SiO}_{x}$ hybrids to $\mathrm{Al}_{2} \mathrm{O}_{3}-\mathrm{C}$ refractories has been shown to improve the mechanical properties of the oxide-C refractory (Wang et al., 2018). Expanded graphite can be coated with nano-SiC. The layer that forms on the expanded graphite is either $\mathrm{SiC}_{x} \mathrm{O}_{y}$ or $\mathrm{SiC}$, depending on the coating temperature. The $\operatorname{SiC}_{x} \mathrm{O}_{y}$ and $\mathrm{SiC}$ layer improves the oxidation of the expanded graphite (Liao et al., 2018).

\section{Carbon-based refractory materials}

In carbon-based refractory materials, carbon typically forms the basis of the aggregate and the binder phase. Carbon aggregate can consist of a blend that includes natural graphite, calcined graphite, calcined coal, petroleum coke, carbon black, calcined anthracite, and artificial graphite (Ewais, 2004; Piel and Schnittker, 2012). Coal-tar pitch, petroleum pitch, and other organic materials are typical binders used in carbon refractory materials. Typical impregnators are coal-tar pitch and polymers. Impregnation is used to modify the properties of the final product (Pierson, 1993).

Figure 3 shows a carbon-based ramming mix prepared for tap-hole applications. Carbon forms the aggregate, and the matrix consists of carbon, oxide compounds ( $\mathrm{Al}, \mathrm{Si}$ ), and some metallic phases. The Al-Si oxide compounds are added for their insulating properties and high strength; metallics are added as anti-oxidants.

\section{Carbon-based monolithic refractory material}

The most common carbon based monolithics are electrode paste and carbon ramming paste.

Electrode paste consists of coke or calcined anthracite as aggregate and coal tar pitch as a binder. It is mainly used to make electrodes but is also sometimes applied as unshaped refractory material (Brun, 1982; Shoko, Beukes, and Strydom, 2013).

The aggregate in carbon paste can consist of calcined anthracite, anthracite, coke, tar, coal tar pitch, resin, or a combination of these can be used as a binder. $\mathrm{Al}_{2} \mathrm{O}_{3}$ and other components can be used as an additive (Hearn, Dzermejko, and Lamont, 1998; Steenkamp et al., 2014). Carbon paste can be used as the refractory lining based on an insulating design philosophy, as is the case for submerged arc furnaces used in the production of silicomanganese (Steenkamp, Pistorius, and Tangstad, 2015c), and it can also be used to fill gaps between carbon-carbon joints.

\section{Carbon-based shaped refractory materials}

There are four classifications of pre-shaped carbon-based refractory materials, i.e. amorphous carbon, semi- or part graphite, semi-semi graphite, and graphite brick (Dzermejko, 2004; Hearn, Dzermejko, and Lamont, 1998).

Manufacturing of pre-shaped refractory materials typically involves mixing aggregate with binders and shaping the mixture, after which it is fired at the required temperatures (Carniglia and Barna, 1992; Piel and Schnittker, 2012). For the shaped refractory materials, the priority is to attain maximum density of the formed shape.

A typical production flow diagram for a carbon refractory is shown in Figure 4. Aggregate, fillers, and binders are milled, sieved, classified to the required particle sizes, then mixed and blended at typically $160-170^{\circ} \mathrm{C}$ (Pierson, 1993). The mixture is then cooled to about $125^{\circ} \mathrm{C}$ and moulded to shape. Three forming techniques are used for shaping the carbon blocks: extrusion, compression, and isostatic pressing. After forming, the shaped product is carbonized by heating to temperatures between $800^{\circ} \mathrm{C}$ and $1400^{\circ} \mathrm{C}$ in an inert atmosphere. This process is called carbonization (Pierson, 1993). The product produced at this stage is called a carbon brick (Goto et al., 2012; Dzermejko, 2004; Hearn, Dzermejko, and Lamont, 1998).

During carbonization, the product becomes porous due to the loss of volatile material. To achieve the required porosity and quality, the product is impregnated with coal-tar pitch

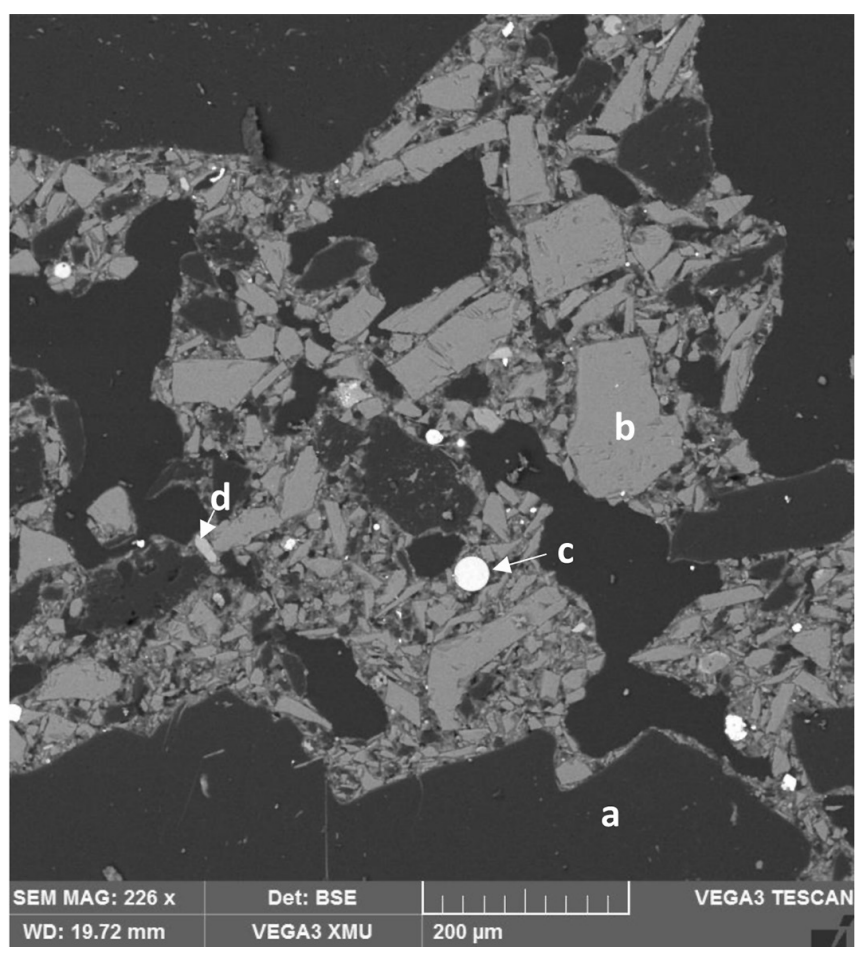

Figure 3-Backscattered electron micrograph of a carbon-based ramming material with (a) carbon as aggregate and a matrix consisting of (b) $\mathrm{Al}_{2} \mathrm{SiO}_{5}$, (c) $\mathrm{Fe}_{3} \mathrm{Si}$, and (d) $\mathrm{FeS}$ 


\section{A review of carbon-based refractory materials and their applications}

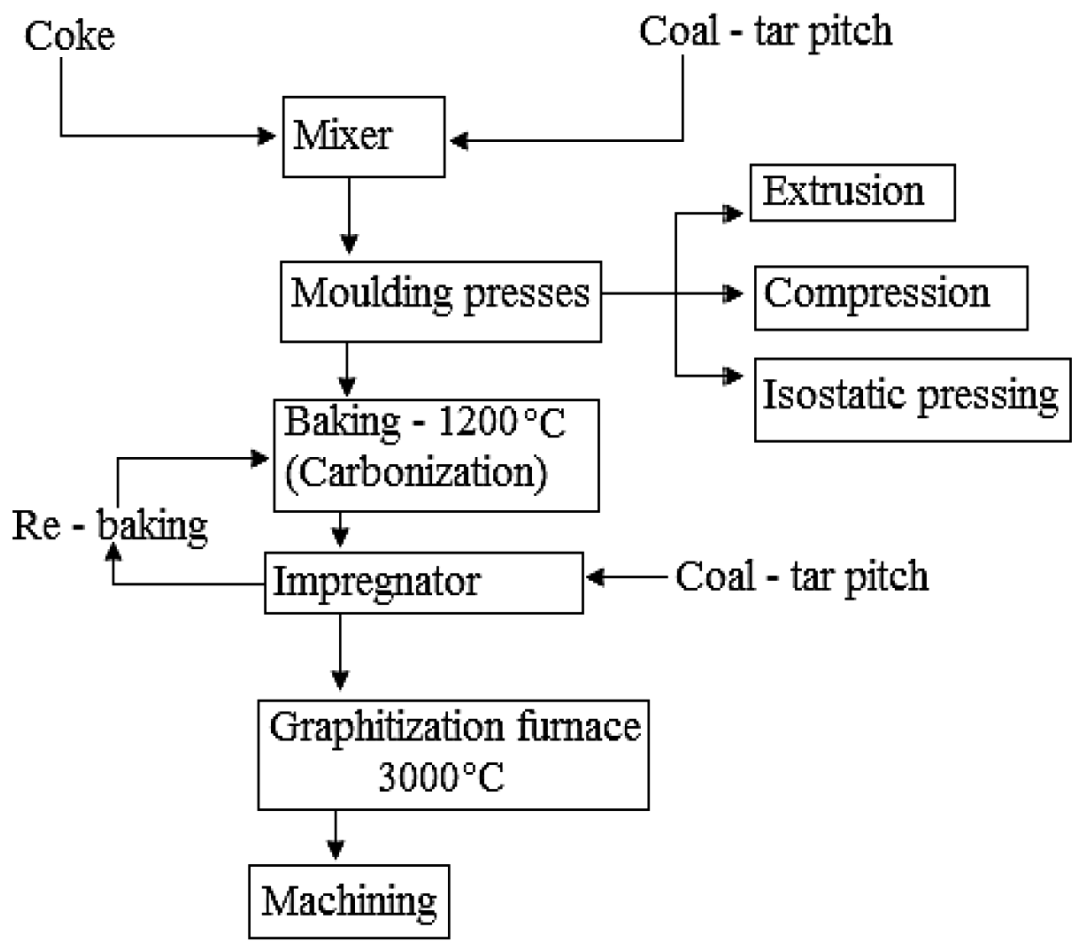

Figure 4-Typical process flow diagram for production of moulded graphite (after Pierson, 1993)

or polymers in a high-pressure autoclave. Impregnation and carbonization are repeated until the required properties are met (Piel and Schnittker, 2012; Dzermejko, 2004). During carbonization the binders are converted to coke (Ewais, 2004).

A carbon brick that contains artificial graphite as aggregate and petroleum pitch or coal tar pitch as a binder is called a semigraphite brick.

A semi-graphite brick is further fired at temperatures of $1600-2200^{\circ} \mathrm{C}$ to produce a semi-semi graphite brick. Semi-semi graphite brick has higher thermal conductivity and resistance to chemical attack than carbon brick and semi-graphite brick (Dzermejko, 2004; Hearn, Dzermejko, and Lamont, 1998).

To produce graphite, semi-graphite brick is further fired at $2400-3000^{\circ} \mathrm{C}$ in a resistance or induction furnace to convert the carbon to a graphitic structure (Pierson, 1993). Graphitization increases the thermal and electrical conductivity of the material as well as the resistance to thermal shock and chemical attack. During graphitization puffing may occur, a condition in which the shaped graphite expands due to the release of volatile species. Puffing causes cracks and other structural defects (Pierson, 1993).

The properties of the raw materials used and the forming process determine the properties and cost of the final product. The most important properties of the raw material include the particle size, ash content, impurities (content and composition), and the degree of graphitization of binders (Pierson, 1993). Extrusion produces a non-uniform, anisotropic, low-cost material. Isostatic pressing produces a material with a more uniform isotropic structure and fewer defects (Pierson, 1993; Dzermejko, 2004). Porosity is reduced by multiple impregnations with binder and re-firing (Dzermejko, 2004).

Carbon blocks have been used in blast furnace linings since the middle of the 20th century (Nitta, Nakamura, and Ishii, 2008). The first carbon blocks were manufactured in 1965 for application in blast furnace hearths, and consisted of roasted anthracite and artificial graphite flakes bonded with tar (Tomala and Basista, 2007; Nitta, Nakamura, and Ishii, 2008). In 1975 alumina was added to improve the corrosion resistance to molten iron. In 1981 metallic Si was added to reduce pore diameter of the brick. In 1994 the calcined anthracite was replaced by graphite and alumina to improve thermal conductivity and resistance to molten iron. Carbon-based shaped refractory materials also form the basis of conductive linings typically applied in submerged arc furnaces producing high-carbon ferromanganese (Hearn, Dzermejko, and Lamont, 1998) or ferrochromium (Coetzee et al., 2010).

Microporous carbon is a carbon-based material that is characterized by low porosity, high resistance to corrosion by metal, and high thermal conductivity (Nitta, Nakamura, and Ishii, 2008; Ewais, 2004). The wear resistance of amorphous carbon and semi-graphite bricks can be improved by additives such as alumina compounds, finely ground silicon compounds, titanium, and titanium oxide (Piel and Schnittker, 2012; Tomala and Basista, 2007). The typical manufacturing process for a microporous carbon refractory involves premixing, shaping, and curing of the components at $200^{\circ} \mathrm{C}$ for 10 hours. The cured sample is put in an alumina crucible and then embedded in graphite and baked at $1400^{\circ} \mathrm{C}$ for 3 hours in an air atmosphere (Chen et al., 2010).

Super-microporous carbon is manufactured the same way as microporous carbon, except that the aggregate for the supermicroporous carbon consists of 50\% graphite particles and $50 \%$ anthracite. Graphite has a higher degree of crystallization than anthracite. The microstructure is bonded with tar of low permeability and low ash content. $\mathrm{SiC}, \mathrm{Si}$, and $\mathrm{Al}_{2} \mathrm{O}_{3}$ are the additives in the microstructure. Double densification is achieved by pitch impregnation under vacuum. The difference between the microporous carbon and the supermicroporous carbon is the proportion of graphite to anthracite and the permeability and ash content of the tar (Silva et al., 2005). 


\section{A review of carbon-based refractory materials and their applications}

Graphite is a nonmetallic carbon-based refractory material that remains chemically and physically inert at high temperatures. Graphite is a good conductor of heat and electricity, it has high stiffness and strength, is chemically inert, and has high corrosion resistance. Graphite can maintain its thermal qualities up to $3600^{\circ} \mathrm{C}$. Graphite can be classified into synthetic and natural graphite, and natural graphite can be further classified into flake, crystalline vein, or lump and amorphous (very fine flake graphite). Synthetic graphite is formed by heat treatment of carbon at $2500-3000^{\circ} \mathrm{C}$ as shown in Figure 4 . In metallurgy, graphite is used as a refractory in the iron, steel, ceramics, and glass production industries, among others. It is used on its own or as a component of an oxide-carbon refractory in crucibles, ladles, moulds, and castings for holding molten metals (Jara et al., 2019).

Graphite refractory is commonly used in blast furnaces at the hearth and tap-holes (Ewais, 2004). It is also used in partial lining of the hearth of furnaces that produce Si, FeSi, and FeMn (Banda, 2019; Steenkamp et al., 2014). In a recent development, graphite blocks are used as a refractory in electric furnaces which produce platinum group metals (Thethwayo and Garbers-Craig, 2014). At present, graphite blocks are used only against the feed and slag zone at the hot face. Graphite has performed well at the feed slag zone of industrial PGM smelters (Thethwayo and Garbers-Craig, 2012; Thethwayo and Cromarty, 2015a). Magnesia-chrome bricks or castables are still used at the hot face of the matte zone in PGM smelters. The application of graphite blocks against the liquid matte is still under investigation. Laboratory tests have shown that graphite is poorly wetted by synthetic and industrial matte (Thethwayo, 2019; Thethwayo and Cromarty, 2015a, 2015b; Thethwayo and Garbers-Craig, 2012 , 2014). As such, penetration of liquid matte due to capillary pressure is not envisaged when graphite is exposed to a liquid matte. Crucible tests conducted on graphite with matte showed that liquid matte penetrates through a porous graphite as a consequence of external forces (such as gas pressure); therefore, although graphite is poorly wetted by matte, physical penetration of liquid matte through graphite can occur if the internal pressure is greater than the capillary pressure. The penetration of liquid matte through graphite can be prevented by using a dense graphite with porosity of $<12 \%$ (Thethwayo, 2019; Thethwayo and Cromarty, 2015a, 2015b).

Graphite has high resistance to chemical attack by liquid matte. A liquid matte phase can lose sulphur due to volatilization at high temperatures, resulting in the formation of a metal phase (FeNi). Graphite dissolution in a sulphide phase is insignificant but a metal phase can dissolve up to $3 \%$ by weight carbon, which is quite significant for graphite consumption over time. Therefore where graphite is used, sulphur loss by the matte should be avoided to prevent dissolution of graphite in a metallic phase (Thethwayo and Cromarty, 2015a; Thethwayo and Garbers-Craig, 2014).

The graphite tested was an extruded, high-porosity $(25 \%$ porosity) synthetic graphite. At this point graphite is used at the concentrate and slag zone in industrial PGM smelters. At the matte zone the conventional refractory bricks are still in use, and the application of graphite against liquid matte has not been commercialized owing to the high matte superheats and anticipated pressure variation inside the furnace, which can cause matte to penetrate through the gaps between graphite blocks as currently observed at the slag-matte interface (Thethwayo, 2019; Thethwayo and Garbers-Craig, 2014).

\section{Conclusion}

Refractory materials play an enabling role in furnace containment system design. Depending on the design philosophy, the physical and/or chemical properties of the refractory material are important. For example, thermal conductivity of the refractory material would be high when a conductive lining design philosophy is applied, and low for an insulating philosophy. As the liquid process materials are in contact with the refractory materials in an insulating lining, chemical compatibility between the refractory materials and the liquid process materials is extremely important. This is the case not only for refractory materials based on the six major oxide components, but also for carbon-based and carbon-containing refractory materials.

For someone new to the field, research can focus either on understanding the applications of existing refractory materials (and the problems associated) or development of new refractory materials. Our research offers examples of the former, where existing refractory materials were evaluated for application in SiMn or PGM production. Our research focused on problems, or potential problems, associated with both applications and contributed to knowledge based on these specific applications. Future research could evaluate alternative materials for the same process applications or look into other applications of the same refractory materials. The alternative materials considered can be either existing or newly developed.

When evaluating refractory material for applications in contact with liquid process materials, one would consider the potential for chemical reactions between the process material and refractory. As a first step, the potential for chemical reactions to occur at equilibrium under specific process conditions (chemical composition, temperature, and partial oxygen or sulphur pressure) can be determined using thermodynamic software. As a next step, laboratory-scale tests, i.e. cup, rotary finger, or sessile drop tests, can be considered. The purpose of these tests is to validate the results obtained through thermodynamic calculations, often based on bulk chemical analyses of the liquid process materials and refractory materials, and determine if some components of the refractory materials react more readily with the process materials. These tests are conducted under conditions that are strictly controlled. Final testing will be on an industrial scale, with prior pilot-scale testing should such facilities be available, with the associated variations in process conditions. An important tool in these evaluations is post-mortem analysis, in which samples of refractory materials obtained from laboratory-, pilot-, or industrial-scale tests are sectioned and studied for infiltration and wear on the macro- and micro-scale. For the former, regular cameras with good lighting conditions are used. For. For the latter, microscopes i.e. optical microscopes, scanning electron microscopes with energy dispersive X-ray spectrometer, and electron microprobe analysers, are useful.

\section{References}

Amavis, R. 1990. Refractories for the Steel Industry. Springer Science \& Business Media.

BANDA, W.K. 2019. Chemical wear of carbon-based refractory material by silicomanganese. MScEng dissertation, University of the Witwatersrand, Johannesburg, South Africa.

BANERJEE, S. 2004. Properties of refractories. Refractories Handbook. Marcel Dekker, New York. pp. 3-9.

BARTHEL, H. 2008. Carbon-containing magnesia and magnesi-carbon bricks. Refractory Materials: Pocket Manual; Design, Properties, Testing. Routschka, G. (ed.). Vulkan-Verlag GmbH. pp. 158-173. 


\section{A review of carbon-based refractory materials and their applications}

Bhol, B., Ray, H.S., and SAHajwalLa, V. 2008. Influence of different parameters on wettability of graphite by $\mathrm{CaO}-\mathrm{SiO}_{2}-\mathrm{FeO}$ molten slag. Journal of the Institution of Engineers (India), Part MM: Metallurgy and Material Science Division, vol. 89. pp. 3-8.

Brosnan, D.A. 2004. Corrosion of refractories. Refractories Handbook. Schacht, C. (ed.). CRC Press. pp. 40-46.

BRUN, H. 1982. Development of refractory linings for electric reduction furnaces producing Mn alloys at Elkem A/S-PEA plant. Journal of the Institute of Refractories Engineers, Spring. pp. 12-23.

Carniglia, S. and Barna, G.L. 1992. Principles of thermal stability. Handbook of Industrial Refractories Technology: Principles, Types, Properties and Applications. Elsevier. pp. 135-142.

Chen, J., Chen, L., Wei, Y., Li, N., and Zhang, S. 2018. Corrosion and penetration behaviors of slag/steel on the corroded interfaces of $\mathrm{Al}_{2} \mathrm{O}_{3}-\mathrm{C}$ refractories: Role of $\mathrm{Ti}_{3} \mathrm{AlC}_{2}$. Corrosion Science, vol. 143. pp. 166-176.

Chen, X., Li, Yawei, Li, Yuanbing, Sang, S., Zhao, L., Li, S., Jin, S., and Ge, S. 2010 Effect of carbon aggregates on the properties of carbon refractories for a blast furnace. Metallurgical and Materials Transactions B, vol. 41. pp. 420-429.

Coetzee, C., Lamont, P.H., Duncanson, P.L., and Sylven, P. 2010. New refractory lining direction at Jindal stainless FeCr \#1 and \#2 furnaces. Proceedings of Infacon XII: Sustainable Future, Helsinki, Finland, 6-9 June 2010. Outotec Oyj, Helsinki. pp. 891-898.

Duncanson, P.L. and Tотн, J.D. 2004. The truths and myths of freeze lining technology for submerged arc furnaces. INFACON X: Transformation through Technology. Proceedings of the Tenth International Ferroalloys Congress, Cape Town, South Africa. South African Institute of Mining and Metallurgy, Johannesburg pp. 488-499.

Dzermejko, A.J. 2004. Properties of refractories. Refractories Handbook. Schacht, C. (ed.), CRC Press. pp. 201-214.

EwaIs, E.M.M. 2004. Carbon based refractories. Journal of the Ceramic Society of Japan, vol. 112. pp. 517-532.

Ghasemi-Kahrizsangi, S., Karamian, E., Ghasemi-Kahrizsang, A., Desheikh, H.G., and SoHeiLy, A. 2017. The impact of trivalent oxide nanoparticles on the microstructure and performance of magnesite-dolomite refractory bricks Materials Chemistry and Physics, vol. 193. pp. 413-420.

Goto, K., Koнno, K., NitTa, M., HanagiRi, S., and Tsutsui, Y. 2012. Development of refractory technology. Technical Report no. 101. Nippon Steel.

Habashi, F. 2002. Textbook of Pyrometallurgy. Métallurgie Extractive Québec. pp. $116-120$

Hearn, A.M, DzermejKo, A.J., and Lamont, P.H. 1998. Freeze lining concepts for improving submerged arc furnace lining life and performance. Proceedings of the 8th International Ferroalloys Congress, Beijing; China; 7-10 June 1998. China Science \& Technology Press, Beijing. pp. 401-426.

Jansson, S., Brabie, V., and Bohlin, L. 2004. Corrosion mechanism and kinetic behaviour of refractory materials in contact with $\mathrm{CaO}-\mathrm{Al}_{2} \mathrm{O}_{3}-\mathrm{MgO}-\mathrm{SiO}_{2}$ slag. Proceedings of the VII International Conference on Molten Slags Fluxes and Salts. Southern African Institute of Mining and Metallurgy, Johannesburg. pp. 341-348.

Jara, A.D., Betemariam, A., Woldetinsae, G., and Kim, J.Y. 2019. Purification, application and current market trend of natural graphite. International journal of Mining Science and Technology. https://doi.org/10.1016/j.ijmst.2019.04.003

Landy, R.A. 2004. Magnesia refractories. Refractories Handbook. Schacht, C. (ed.). CRC Press. pp. 109-149.

LEE, W.E. and ZHANG, S. 2004. Direct and indirect slag corrosion of oxide and oxide-C refractories. Proceedings of the VII International Conference on Molten Slags Fluxes and Salts. South African Institute of Mining and Metallurgy, Johannesburg. pp. 309-320.

LeE, W.E. And Zhang, S. 1999. Melt corrosion of oxide and oxide-carbon refractories. International Materials Reviews, vol. 44. pp. 77-104.

LiAo, N., L, Y., Shan, J., SANG, S., and JiA, D. 2018. Improved oxidation resistance of expanded graphite through nano SiC coating. Ceramics International, vol. 44. pp. 3319-3325.

LindSTAD, L. and Aursjø, S. 2018. Monolithic furnace linings for production of ferroalloys. Proceedings of the Fifteenth International Ferro-Alloys Congress, Cape Town, South Africa. 25-28 February. Southern Africn Institute of Mining and Metallurgy, Johannesburg. pp. 30-40.

NitTA, M., NaKAmura, H., and Ishil, A. 2008. Development of carbon blocks for blast furnace hearth. Shinnittetsu Giho (Nippon Steel Technical Report), vol. 388. pp. 48-54.

Piel, K. and SchnitTKer, A. 2012. Carbon and graphite bricks. Handbook of Refractory Materials: Design, Properties, Testing. Routschka, G.and Wuthnow, H. (eds.). Vulkan-Verlag, Essen. pp. 48-51.

Pierson, H.O. 1993. Molded graphite: Processing, properties and applications. Handbook of Carbon, Graphite, Diamond and Fullerenes. Properties, Processing and Applications. Elsevier. pp. 87-110.
Richmond, C. 2004. Doloma refractories. Refractories Handbook. Schacht, C. (ed.), CRC Press. pp. 184-199.

Rigaud, M. 2011. Corrosion of refractories and ceramics. Uhlig's Corrosion Handbook. Winston Revie, R. (ed.). Wiley. pp. 387-398.

RoutschKa, G. and BARTHEL, H. 2008. Introduction. Refractory Materials: Pocket Manual; Design, Properties, Testing. Routschka, G. (ed.), Vulkan-Verlag GmbH. pp. $1-16$.

ScHACHT, C. 2004. Refractories Handbook. CRC Press.

SHen, P., FujI, H., and Nogi, K. 2009. Wettability of some refractory materials by molten $\mathrm{SiO}_{2}-\mathrm{MnO}-\mathrm{TiO}_{2}-\mathrm{FeO}_{\mathrm{x}}$ slag. Materials Chemistry and Physics, vol. 114. pp. 681-686.

Sноко, L., Beukes, J.P., and Strydom, C.A. 2013. Determining the baking isotherm temperature of Söderberg electrodes and associated structural changes. Minerals Engineering, vol. 49. pp. 33-39.

Silva, S.N., Vernilli, F., Justus, S.M., Maroues, O.R., Mazine, A., Baldo, J.B., Longo, E., and VARELA, J.A. 2005. Wear mechanism for blast furnace hearth refractory lining. Ironmaking \& Steelmaking, vol. 32. pp. 459-467.

STEENKAmP, J.D. 2014. Chemical wear of carbon-based refractory materials in a silicomanganese furnace tap-hole. PhD thesis, University of Pretoria.

Steenkamp, J., KotZÉ, H., Meyer, J., and Barnard, J. 2011. Magnesia refractory dryoutmanaging the risk of hydration. Journal of the Southern African Institute of Mining and Metallurgy, vol. 111. pp. 423-428.

Steenkamp, J.D., Gous, J.P., Pistorius, P.C., TAngstad, M., and Zietsman, J.H. 2014. Wear analysis of a taphole from a SiMn production furnace. Proceedings of the Furnace Tapping Conference 2014. Southern African Institute of Mining and Metallurgy, Johannesburg. pp. 51-64.

SteEnkamp, J.D., Pistorius, P.C., and TAngstad, M. 2015a. Wear mechanisms of carbonbased refractory materials in silicomanganese tap-holes - Part 1: equilibrium calculations and slag and refractory characterisation. Metallurgical and Materials Transactions B: Process Metallurgy \& Materials Processing Science, vol. 46B. pp. 653-667. https://doi.org/DOI 10.1007/s11663-014-0275-9

SteEnkamp, J.D., Pistorius, P.C., and TAngstad, M. 2015b. Wear mechanisms of carbonbased refractory materials in SiMn tap-holes - Part 2: In-situ observation of chemical reactions. Metallurgical and Materials Transactions B: Process Metallurgy \& Materials Processing Science, vol. 46B. pp. 668-679. https://doi. org/DOI 10.1007/s11663-014-0276-8

Steenkamp, J.D., Pistorius, P.C., and Tangstad, M. 2015c. Chemical wear analysis of a tap-hole on a SiMn production furnace. Journal of the Southern African Institute of Mining and Metallurgy, vol. 115, no. 3. pp. 199-208.

Steenkamp, J.D., Denton, G.M., and Hayman, D.A. 2017. Insulating or conductive lining designs for electric furnace smelting? Applications of Process Engineering Principles in Materials Processing, Energy and Environmental Technologies: A Symposium in Honor of Professor Ramana G. Reddy. The Minerals, Metals \& Materials Society, San Diego, CA. pp. 209-220. https://doi.org/DOI 10.1007/978-3-319-51091-0 19

Stevenson, A. 2010. English I Oxford Dictionaries.

Thethwayo, B.M. 2019. Interaction of carbon-based refractories with liquid PGMfurnace melt. $\mathrm{PhD}$ thesis, University of Pretoria.

ThethwAYo, B.M. and Garbers-Craig, A.M. 2012. Interaction of graphite with synthetic matte. Proceedings of the 5th International Platinum Conference: 'A Catalyst for Change', Sun City, South Africa. Southern African Institute of Mining and Metallurgy, Johannesburg. pp. 261-274.

Thethwayo, B.M. and Garbers-Craig, A.M. 2014. Wear of graphite and micropore carbon by synthetic PGM matte. Proceedings of the Unified International Technical Conference on Refractories. Wiley, USA. pp. 1067-1074.

THeTHWAYo, B.M. and CRomaRTY, R.D. 2015a. Compatibility of graphite with primary platinum group metals industrial matte. Materials Research Innovations, vol. 19. pp. 948-952.

Thethwayo, B.M. and Cromarty, R.D. 2015b. Wettability of graphite by synthetic and industrial PGM-furnace matte. Ceramica, vol. 61. pp. 219-223.

Tomala, J. and Basista, S. 2007. Micropore carbon furnace lining. Proceedings of INFACON XI, New Delhi, India, 18-21 February 2007. Indian Ferro Alloy Producers Association. pp. 722-727.

WAng, Q., LI, Y., Jin, S., SAng, S., Xu, Y., Xu, X., and WAnG, G. 2018. Enhanced mechanical properties of $\mathrm{Al}_{2} \mathrm{O}_{3}-\mathrm{C}$ refractories with silicon hybridized expanded graphite. Materials Science and Engineering A, vol. 709. pp. 160-171.

XIAo, J., Chen, J., WeI, Y., Zhang, Y., Zhang, S., and LI, N. 2019. Oxidation behaviors of $\mathrm{MgO}-\mathrm{C}$ refractories with different $\mathrm{Si} / \mathrm{SiC}$ ratio in the $1100-1500^{\circ} \mathrm{C}$ range. Ceramics international, vol. 45. pp. 21099-21107.

YAo, H., Xing, X., Wang, E., LI, B., Chen, J., Sun, J., and Hou, X. 2017. Oxidation behavior and mechanism of $\mathrm{Al}_{4} \mathrm{SiC}_{4}$ in $\mathrm{MgO}-\mathrm{C}-\mathrm{Al}_{4} \mathrm{SiC}_{4}$ system. CoatingS, vol. 7 . p. 85. https://www.mdpi.com/2079-6412/7/7/85/pdf

Zhang, S. and LeE, W.E. 2004. Spinel-containing refractories. Refractories Handbook. Schacht, C. (ed.). CRC Press. pp. 251-253. 